\section{Effects of Core Cultivation Tine Entry Angle on Golf Putting Greens}

\author{
Christian M. Baldwin ${ }^{1}$, Haibo Liu ${ }^{1,2}$, and Philip J. Brown ${ }^{3}$
}

ADDITIONAL INDEX WORDs. 'Crenshaw' creeping bentgrass, water infiltration, hollow tines, soil hydrophobicity, compaction, turf quality, localized dry spots, thatch, MED

SUMMARY. Hollow tine cultivation is a routine practice on golf course putting greens, where the tine entry angle normally is $90^{\circ}$. Effects of various tine entry angles impacting putting green surfaces have not been investigated. The hypothesis was that different tine entry angles during cultivation would impact a greater area of the soil profile by enhancing water infiltration rates, reducing localized dry spots, and enhancing turf quality. Therefore, a 2-year field study in 2003 and 2004 was conducted to determine the impact of core cultivation tine entry angle on 'Crenshaw' creeping bentgrass (Agrostis stoloniferous var. palustris). Treatments included three angles of hollow tine entry at $50^{\circ}, 70^{\circ}$, and $90^{\circ}$ and an untreated plot without cultivation. Manual cultivators consisted of four 1/4inch- and 1/2-inch-diameter hollow tines 3 inches in length, spaced 2 inches apart. Treatment applications were in April, May, September, and October. Measurements included visual turfgrass quality (TQ), molarity ethanol droplet test (MED), and water infiltration. No treatment (control, $50^{\circ}, 70^{\circ}, 90^{\circ}$ ) effects in years I and II for TQ were noted. MED scores in May were 23\% higher than in August and September. Tines of 1/2-inch diameter reduced soil hydrophobicity (MED) $6 \%$ compared to tines of $1 / 4$-inch-diameter tines. Tines of $50^{\circ}, 70^{\circ}$, and $90^{\circ}$ had $129 \%, 163 \%$, and $211 \%$ greater water infiltration than the untreated, respectively.

S oil compaction is a process that involves macropore reduction where the soil surface is compressed by foot, maintenance equipment, or vehicle traffic. Compacted soils are more dense with less pore space, leading to restricted water flow and root growth (Carrow and Petrovic, 1992). Therefore, to remedy soil compaction and related problems, cultivating with either hollow or solid tines is a common practice on golf putting greens. Hollow tine cultivation removes soil cores with grass from turf surface by leaving holes to reduce soil compaction (McCarty, 2005). Cultivation improves root growth by reducing soil strength and bulk density and increasing soil porosity (Fry and Huang, 2004). Hartwiger and O'Brien (2001) recommended that

Clemson University, Clemson, SC 29634-0319.

The authors thank Dr. Bert McCarty for providing the study green; Mr. Don Garrett and Mr. Alan Estes for the maintenance of the research site; and Mr. Alan Garrett for manufacturing the cultivators used for the study at Clemson University.

${ }^{1}$ Department of Horticulture, D-136 Poole Agricultural Center.

${ }^{2}$ Corresponding author: haibol@clemson.edu

${ }^{3}$ Department of Crop and Soil Environmental Science.
$15 \%$ to $20 \%$ of surface area for mature greens be removed as cores annually to efficiently reduce compaction and maintain sufficient soil/air oxygen and water exchange.

Cultivation has become a routine practice for turfgrass managers because it relieves compaction; allows deeper / faster water, air, and fertilizer penetration; reduces localized dry spots; and removes and controls thatch by promoting soil microorganism activity (McCarty, 2005). Excessive thatch is detrimental to putting green turf, allowing insect invasion and increased disease incidence, as well as increased scalping potential from mowing ( $\mathrm{Mc}$ Carty, 2005). Thatch also negatively affects drought tolerance, cold tolerance, and water infiltration rates (White and Dickens, 1984).

Localized dry spots (LDS) tend to occur during stressful, warm summer months and are problematic on greens with a sandy soil profile. Pos- sible causes for LDS include excessive thatch, high-bulk-density soils, poor irrigation coverage, steep sloping grade, or hydrophobic soils (Tucker et al., 1990). Wilkinson and Miller (1978) noted that LDS appearing on 'Penncross' creeping bentgrass sand-based golf green was particularly attributed to an organic coating, later identified as fulvic acid deposited by microbial activities under limited cultivation conditions (Miller and Wilkinson, 1979).

Factors affecting cultivation include soil moisture, tine size, penetration depth, soil texture, cultivation frequency, and equipment type (Guertal and Han, 2002). Different techniques to reduce compaction and thatch for turfgrass managers include linear cultivation, which is designed to treat the upper level of the soil to preserve surface diffusion rates (Jones, 2002); vertical mowing (Hollingsworth et al., 2005; McCarty et al., 2005; White and Dickens, 1984); deep-tine cultivation (Guertal et al., 2003); and high-pressure water injection (Murphy and Rieke, 1994). However, effects of cultivation with different tine entry angles on soil hydrophobicity (dry spots) and water infiltration rates have not been investigated. The authors hypothesize that cultivating with different tine entry angles (alternating with each cultivation date) will impact a greater area of the soil profile, thereby enhancing water infiltration rates, reducing localized dry spots, and enhancing TQ. Therefore, the objective of this research was to determine effects of tine diameter and entry angle on TQ, soil hydrophobicity, and water infiltration rates on a creeping bentgrass putting green surface.

\section{Materials and methods}

A 2-year field study was conducted in 2003 and 2004 on Clemson University's 'Crenshaw' creeping bentgrass field research plots constructed in 1997 with 85 sand : 15 peat root-zone mix (by volume) according to U.S. Golf Association (USGA) recommendations (Table 1) (USGA,

\begin{tabular}{lllc}
\hline $\begin{array}{l}\text { Units } \\
\text { To convert U.S. to SI, } \\
\text { multiply by }\end{array}$ & U.S. unit & SI unit & $\begin{array}{l}\text { To convert SI to U.S., } \\
\text { multiply by }\end{array}$ \\
\hline 29.5735 & $\mathrm{fl} \mathrm{oz}$ & $\mathrm{mL}$ & 0.0338 \\
2.54 & inch $(\mathrm{es})$ & $\mathrm{cm}$ & 0.3937 \\
25.4 & inch $(\mathrm{es})$ & $\mathrm{mm}$ & 0.0394 \\
1.1209 & lb $/$ acre & $\mathrm{kg} \cdot \mathrm{ha}^{-1}$ & 0.8922
\end{tabular}


1993). The green was mowed daily at $1 / 2$ inch and irrigated with approximately $\mathrm{l}$ inch of water weekly. Soil $\mathrm{pH}$ was 6.7 and fungicides of chlorothalonil and azoxystrobin were applied every 14 or $28 \mathrm{~d}$, respectively, to control or suppress diseases for each season. Each year, fertility applications provided $346 \mathrm{lb} /$ acre nitrogen, 37 $\mathrm{lb} /$ acre phosphorus, and $145 \mathrm{lb} / \mathrm{acre}$ potassium.

Cultivation treatments were initiated in Mar. 2003 and continued in May, September, and October, and repeated in 2004. Plot size was $24 \times$ 48 inches. During the entire study, treatments included $50^{\circ}, 70^{\circ}, 90^{\circ}$ hollow-tine manual cultivators and an untreated control without cultivation during the whole study period. Manual cultivators were constructed at the Clemson University maintenance facility department consisting of four 1/4-inch- and 1/2-inch-diameter hollow tines 3 inches long, spaced 2 inches apart (Figs. 1 and 2). Each entry angle treatment was applied manually ( 264 holes/plot). Once cultivation was complete, all cores were removed and topdressing was performed using USGA-specified sand for putting greens. Sand was applied by hand and incorporated into turf by brushing, using hand brooms, until all holes were completely filled. Cultivation direction varied with each treatment application (north in March, south in May, east in September, and west in October).

Data Collection. Data collected included TQ, MED test, and water infiltration rates. Turf quality ratings were recorded monthly based on color, density, texture, and uniformity of the bentgrass surface. Quality was rated from 1 to 9 , where $1=$ brown, dead turf; $6=$ minimal acceptable turf; and 9 = ideal green, healthy turf.

Soil hydrophobicity was tested using the MED technique (Table 2) (King, 1981). Two undisturbed soil core samples ( 5 inches deep and $1 / 2$ inch in diameter) were randomly taken monthly from each plot prior to cultivation treatments and allowed to air dry for $14 \mathrm{~d}$. Droplets containing various molarity concentrations of ethanol and distilled water solution were placed on each soil sample (3 inches down the length of the core) using a pipette. A scale of 0.0 to 4.0 , based on the molarity of ethanol of the solution tested, was used, with 4.0 being severely hydrophobic and 0.0
Table 1. Sand fraction of soil physical properties of soil media at the 'Crenshaw' creeping bentgrass field research plots at Clemson University, Clemson, S.C.

\begin{tabular}{lccccc}
\hline & Very coarse & Coarse & Medium & Fine & Very fine \\
\hline Particle size $(\mathrm{mm})^{\mathrm{z}}$ & $1.00-2.00$ & $0.5-1.0$ & $0.25-0.50$ & $0.10-0.15$ & $0.05-0.10$ \\
Water retained $(\%$ by wt) & 5.6 & 35.3 & 44.6 & 11.1 & 1.7 \\
\hline
\end{tabular}

${ }^{\mathrm{z}} 1 \mathrm{~mm}=0.0394$ inch.

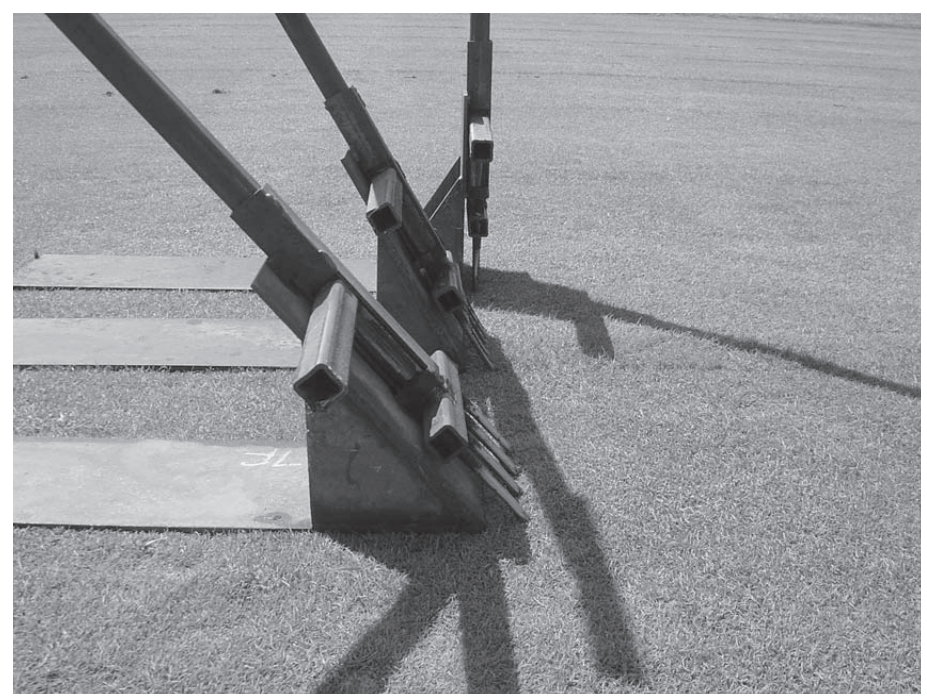

Fig. 1. Individual manual cultivators ( $1 / 4$-inch-diameter tines) used to cultivate a 'Crenshaw' creeping bentgrass green at $50^{\circ}, 70^{\circ}$, and $90^{\circ}$ core cultivation tine entry angles four times from March to October, 2003 and 2004, at Clemson University's field research plots. The $1 / 2$-inch-diameter tine manual cultivator is identical in design except for tine diameter $(1$ inch $=25.4 \mathrm{~mm})$.

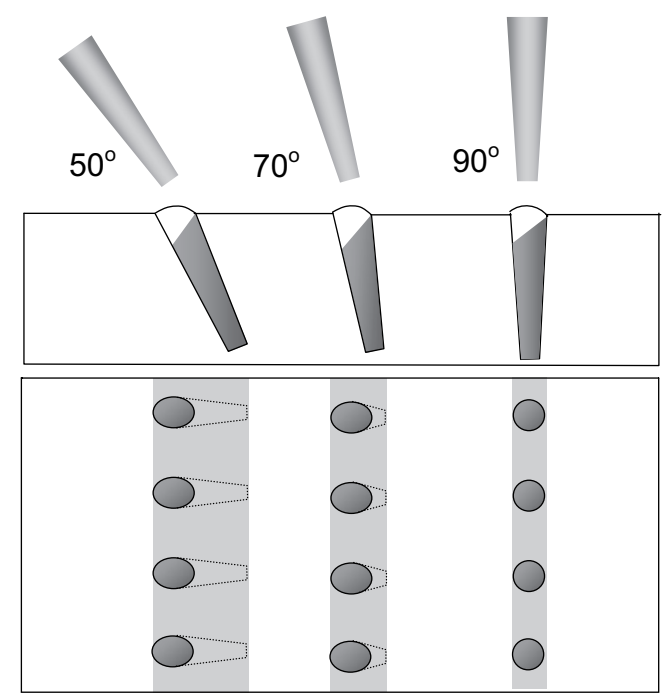

Fig. 2. Impacts of core cultivation tine entry angles of $50^{\circ}, 70^{\circ}$, and $90^{\circ}$. The gray areas show the impacted turf area with various tine entry angles. Compared to $90^{\circ}$ tine entry angle, the various angled tine entries increased the core surface area by $32.8 \%$ and $6.1 \%$ for entry angels of $50^{\circ}$ and $70^{\circ}$, respectively, regardless of tine diameters. Calculation of $50^{\circ}$ entry angle of $1 / 2$-inch-diameter tine surface impact: the percent increase $=\left(\right.$ the oval area impacted - regular $90^{\circ}$ entry tine area $) /$ regular $90^{\circ}$ entry tine area $\times 100 \%=\{\{[(12.7+12.7 \times(1 / \mathrm{Cos}$ $\left.\left.\left.\left.\left.\left(90^{\circ}-50^{\circ}\right)\right)\right) / 2\right] / 2\right\} \times\left\{\left[\left(12.7+12.7 \times\left(1 / \operatorname{Cos}\left(90^{\circ}-50^{\circ}\right)\right)\right) / 2\right] / 2\right\} \times 3.14\right\}$ $-\{(12.7 / 2) \times(12.7 / 2) \times 3.14\} /\{(12.7 / 2) \times(12.7 / 2) \times 3.14\} \times 100 \%=32.8 \%$ and similar calculation for $70^{\circ}$. The longest diameter of oval $=$ the perfect circle diameter $\times 1 / \operatorname{Cos}\left(90^{\circ}-\right.$ the entry tine angle $)$. $\operatorname{Cos} 40^{\circ}=0.766$ and $\operatorname{Cos} 20^{\circ}=$ $0.940(1$ inch $=25.4 \mathrm{~mm})$. 
Table 2. Ethanol/distilled water solution calculations for the molarity of ethanol droplet (MED) test.

\begin{tabular}{|c|c|c|c|}
\hline$\underline{\text { MED }^{z}}$ & $\begin{array}{c}\text { Ethanol } \\
\text { added }\end{array}$ & $\begin{array}{c}\text { Distilled } \\
\text { water } \\
\text { added }\end{array}$ & Total \\
\hline & & $\mathrm{mL}^{\mathrm{y}}$ & - \\
\hline $0.0^{y}$ & 0.00 & 100 & 100 \\
\hline 0.4 & 2.34 & 97.66 & 100 \\
\hline 0.8 & 4.66 & 95.34 & 100 \\
\hline 1.2 & 7.00 & 93.00 & 100 \\
\hline 1.6 & 9.32 & 90.68 & 100 \\
\hline 2.0 & 11.66 & 88.34 & 100 \\
\hline 2.4 & 14.00 & 86.00 & 100 \\
\hline 2.8 & 16.32 & 83.68 & 100 \\
\hline 3.2 & 18.66 & 81.34 & 100 \\
\hline 3.6 & 21.00 & 79.00 & 100 \\
\hline 4.0 & 23.34 & 76.66 & 100 \\
\hline
\end{tabular}

being hydrophilic. If the entire droplet did not completely infiltrate the soil sample within $5 \mathrm{~s}$, the next highest molarity of ethanol/distilled water was applied adjacent (down the length of the core) to the initial drop until the entire droplet was fully absorbed by the soil sample. Soil hydrophobicity increases as the molarity of the ethanol/distilled water solution increases, until the droplet completely infiltrates the soil sample within $5 \mathrm{~s}$.

Water infiltration analysis (Bunnell et al., 2001) was performed in November following yearly cultivation treatments using a double-ring infiltrometer (model 13a; Turf-Tec International, Oakland Park, Fla.). One sample was taken per plot. The outer ring had a diameter of 12 inches and the inner ring, a 6-inch diameter. The infiltrometer was inserted into the turf at a depth of 1 inch. Rings were then filled to the top of the infiltrometer (4 inches) with water. After water vacated the center ring, infiltration rates were recorded based on how long the water took to absorb fully into the soil.

Data ANALYsis. Treatments were arranged as a randomized completeblock design. Main effects and interaction effects were evaluated using analysis of variance (Table 3 ) within SAS (version 9.1; SAS Institute, Cary, N.C.). Significant interactions between years I and II occurred for TQ and water infiltration; therefore, data from each year were statistically analyzed separately. MED years I and II results were combined because there were no significant interactions between

Table 3. Significance of variances for turfgrass quality (TQ) of 'Crenshaw' creeping bentgrass, molarity of ethanol droplet (MED) test, and water infiltration rates affected by tine diameter, treatment, and month.

\begin{tabular}{|c|c|c|c|c|c|}
\hline \multirow[t]{2}{*}{ Source } & \multicolumn{2}{|c|}{$\mathrm{TQ}^{\mathrm{z}}$} & \multirow{2}{*}{$\frac{\text { MED }^{y}}{\text { Year I } \times \text { Year II }}$} & \multicolumn{2}{|c|}{ Water infiltration $^{\mathrm{x}}$} \\
\hline & Year I & Year II & & Year I & Year II \\
\hline Block & NS & NS & NS & NS & NS \\
\hline Tine diam (TD) & ** & NS & $* * * *$ & NS & * * \\
\hline Treatment (TR) & NS & NS & NS & NS & $* * * *$ \\
\hline Month $(\mathrm{M})$ & $* * * *$ & $* * * *$ & $* * * *$ & NS & --- \\
\hline $\mathrm{TD} \times \mathrm{TR}$ & NS & NS & NS & NS & NS \\
\hline $\mathrm{TD} \times \mathrm{M}$ & NS & NS & NS & NS & --- \\
\hline $\mathrm{TR} \times \mathrm{M}$ & NS & NS & NS & NS & --- \\
\hline $\mathrm{TD} \times \mathrm{TR} \times \mathrm{M}$ & NS & NS & NS & NS & --- \\
\hline
\end{tabular}

${ }^{2}$ Year I and II interactions were significant at $P \leq 0.05$.

Yyear I and II interactions were nonsignificant at $P \leq 0.05$

xYear I and II interactions were significant at $P \leq 0.05$

${ }_{\mathrm{Ns},}^{*}, * *, * * *, * * * *$ Nonsignificant or significant at $P \leq 0.05,0.10,0.05,0.01$, or 0.0001 , respectively.

Table 4. Turfgrass quality of 'Crenshaw' creeping bentgrass influenced by month (May-October), cultivation treatments $\left[50^{\circ}, 70^{\circ}\right.$, $90^{\circ}$ core cultivation tine entry angles plus an untreated plot (no cultivation)], and tine diameter (hollow tines, $1 / 4$ or $1 / 2$ inch diameter) during year $\mathrm{I}$.

\begin{tabular}{|c|c|c|c|c|c|}
\hline \multicolumn{6}{|c|}{ Turfgrass quality (1-9 scale $)^{\mathrm{z}}$} \\
\hline \multicolumn{2}{|c|}{ Month } & \multicolumn{2}{|c|}{ Tine entry angle } & \multicolumn{2}{|c|}{ Tine diam (inches) ${ }^{y}$} \\
\hline May & $5.21 c^{x}$ & Untreated & 6.05 & $1 / 4$ & $6.11 \mathrm{a}$ \\
\hline June & $5.21 \mathrm{c}$ & $50^{\circ}$ & 6.08 & $1 / 2$ & $5.90 \mathrm{~b}$ \\
\hline July & $5.87 \mathrm{~b}$ & $70^{\circ}$ & 6.00 & & \\
\hline August & $6.21 b$ & $90^{\circ}$ & 5.88 & & \\
\hline September & $6.70 \mathrm{a}$ & & & & \\
\hline October & $6.83 a$ & & & & \\
\hline LSD & 0.34 & LSD & 0.27 & LSD & 0.19 \\
\hline$P$ & 0.01 & $P$ & 0.51 & $P$ & 0.03 \\
\hline
\end{tabular}

years. Main effect means for TQ, MED, and water infiltration rates are reported because month, treatment, and tine diameter interactions were nonsignificant. Means separation was analyzed using Fisher's least significant difference test at $P=0.05$.

\section{Results and discussion}

Turf Quality. There were no cultivation treatment effects in year I or year II for TQ. Once cultivation treatments were initiated, TQ scores increased to $5.9,6.2,6.7$, and 6.8 in July, August, September, and October compared to May and June ratings (5.2), respectively (Table 4). Cultivation treatments enhancing TQ have previously been reported. Brown (2004) noted an 8\% TQ decline in untreated plots compared to two $90^{\circ}$ hollow ( $3 / 8$ inch) tine cultivation treatments on common bermudagrass (Cynodon dactylon). Bunnell et al.
(2001) reported a TQ enhancement using needle tine $(1 / 3$-inch tine diameter, 5 -inch tine depth) treatments during the summer on 'Crenshaw' and 'Penn A-1' creeping bentgrass. Also, Murphy et al. (1993) observed a TQ improvement following hollow tine cultivation treatments on 'Penneagle' creeping bentgrass. The $1 / 4$-inch tines showed a significant turf quality $(6.1)$ enhancement compared to the $1 / 4$ inch tine (5.9). Although statistically significant, this minor difference may be inconsequential. Unlike year I, tine diameter had no significant impact on TQ in year II (Table 5). Highest TQ was recorded in September, but declined to 6.0 in October. As expected, August TQ was deemed unacceptable $(<6)$ due to summer stress. In years I and II of this study, tine entry angle had no effect on TQ.

MOLARITY ETHANOL DROP TEST. Tine entry angle did not affect MED 
results (Table 6). Sampling month had the greatest impact on MED. May had $13 \%, 23 \%, 31 \%$, and $28 \%$ greater MED scores than June, July, August, September, and October, respectively, indicating reduced soil hydrophobicity in summer and fall, more hydrophobic in spring. Tucker et al. (1990) noted in a survey of 10 golf courses and the University of Georgia Experimental Golf Green that water droplet penetration times was much higher in LDS cores than in healthy adjacent cores.

Tine diameter impacted MED results. The smaller tine diameter (1/4-inch) increased MED 6\% compared to the $1 / 2$-inch tine. Wilkinson and Miller (1978) stated cultivating reduced dry spot severity on a 'Penncross' creeping bentgrass sand golf green. Localized dry spots can occur when water infiltration in certain areas is reduced. For turfgrass managers, it may be more beneficial to use a larger tine diameter as a management practice to minimize undesirable dry patches of turf on a sand-based putting green. Compared to the $90^{\circ}$ tine entry angle, various angled tine entries increased the core surface area by $32.8 \%$ and $6.1 \%$ for entry angles of $50^{\circ}$ and $70^{\circ}$, respectively, regardless of tine diameters (Fig. 2).

Water infiltration. No water infiltration differences due to tine entry angle occurred. However, tine diameter impacted infiltration rates (Table 7 ). The $1 / 4$-inch tine had a $34 \%$ greater infiltration rate than the $1 / 2$-inch tine. The larger diameter tine might have had a greater potential to create a hard pan below the cultivated layer, which might cause slower water infiltration. This result indicates the importance of alternating tine lengths and tine diameters to prevent hard pan formation. However, further investigations are needed.

Without cultivation, water infiltration was reduced by $129 \%, 163 \%$, and $211 \%$ compared to the $50^{\circ}, 70^{\circ}$, and $90^{\circ}$ treatments, respectively. McCarty et al. (2005) noted 188\% greater water infiltration with cultivation treatments compared to the untreated on an 'L-93' creeping bentgrass green with USGA 85 sand: 15 peat mix root zone. Brown (2004) reported a $31 \%$ higher infiltration rate after four deep-tine cultivation treatments compared with untreated plots on
Table 5. Turfgrass quality of 'Crenshaw' creeping bentgrass influenced by month (May-October), cultivation treatments $\left[50^{\circ}, 70^{\circ}\right.$, $90^{\circ}$ core cultivation tine entry angles plus an untreated plot (no cultivation)], and tine diameter (hollow tines, $1 / 4$ - or $1 / 2$-inch diameter) during year II.

\begin{tabular}{lccccc}
\hline \multicolumn{5}{c}{ Turfgrass quality (1-9 scale) $)^{\mathrm{z}}$} \\
\hline \multicolumn{7}{c}{ Month } & \multicolumn{4}{c}{ Tine entry angle } & Tine diam (inches) \\
\hline May & $6.33 \mathrm{~b}^{\mathrm{y}}$ & Untreated & 6.11 & $1 / 4$ & 6.27 \\
June & $6.54 \mathrm{ab}$ & $50^{\circ}$ & 6.22 & $1 / 2$ & 6.30 \\
July & $6.25 \mathrm{bc}$ & $70^{\circ}$ & 6.44 & & \\
August & $5.95 \mathrm{c}$ & $90^{\circ}$ & 6.39 & & \\
September & $6.70 \mathrm{a}$ & & & & \\
October & $5.95 \mathrm{c}$ & & & & \\
LSD & 0.36 & LSD & 0.29 & LSD & 0.21 \\
$P$ & 0.01 & $P$ & 0.09 & $P$ & 0.78 \\
\hline
\end{tabular}

${ }^{2}$ Turfgrass quality based on a scale of $1-9 ; 1=$ brown $/$ dead turf; $6=$ minimally acceptable turf; 9 $=$ ideal green, healthy turf.

${ }^{y} \mathrm{l}$ inch $=25.4 \mathrm{~mm}$.

xValues within a column followed by the same letter are not significantly different at $P \leq 0.05$ by Fisher's protected least significant difference (LSD).

Table 6. Molarity of ethanol droplet (MED) test results of 'Crenshaw' creeping bentgrass influenced by month (May-October), cultivation treatments $\left[50^{\circ}, 70^{\circ}, 90^{\circ}\right.$ core cultivation tine entry angles plus an untreated plot (no cultivation)], and tine diameter (hollow tines, 1/4- or 1/2-inch diameter) for years I and II.

\begin{tabular}{|c|c|c|c|c|c|}
\hline \multicolumn{6}{|c|}{$\operatorname{MED}(1-4 \text { scale })^{\mathrm{z}}$} \\
\hline \multicolumn{2}{|c|}{ Month } & \multicolumn{2}{|c|}{ Tine entry angle } & \multicolumn{2}{|c|}{ Tine diam (inches) ${ }^{\mathrm{y}}$} \\
\hline May & $1.85 \mathrm{a}^{\mathrm{x}}$ & Untreated & 1.56 & $1 / 4$ & $1.59 \mathrm{a}$ \\
\hline June & $1.64 \mathrm{~b}$ & $50^{\circ}$ & 1.56 & $1 / 2$ & $1.49 \mathrm{~b}$ \\
\hline July & $1.50 \mathrm{c}$ & $70^{\circ}$ & 1.53 & & \\
\hline August & $1.41 \mathrm{c}$ & $90^{\circ}$ & 1.51 & & \\
\hline September & $1.41 \mathrm{c}$ & & & & \\
\hline October & $1.45 \mathrm{c}$ & & & & \\
\hline LSD & 0.11 & LSD & 0.09 & LSD & 0.06 \\
\hline$P$ & 0.01 & $P$ & 0.59 & $P$ & 0.01 \\
\hline
\end{tabular}

${ }^{\mathrm{z}} \mathrm{MED}$ results based on a scale of $1-4 ; 1=$ hydrophilic; 4 = severely hydrophobic.

y 1 inch $=25.4 \mathrm{~mm}$.

xalues within a column followed by the same letter are not significantly different at $P \leq 0.05$ by protected Fisher's protected least significant difference (LSD).

Table 7. Water infiltration rates of 'Crenshaw' creeping bentgrass influenced by cultivation treatments $\left(50^{\circ}, 70^{\circ}\right.$, $90^{\circ}$ core cultivation tine entry angles plus an untreated plot (no cultivation), and tine diameter (hollow tines, 1/4- or 1/2-inch diameter) for year II.

\begin{tabular}{lccc}
\hline & \multicolumn{3}{c}{ Water infiltration rate $(\text { inches } / \mathbf{h})^{\mathrm{z}}$} \\
\cline { 2 - 4 } & Tine entry angle & Tine diam (inches) \\
\hline Control & $9.21 \mathrm{~b}^{\mathrm{y}}$ & $1 / 4$ & $17.8 \mathrm{~b}$ \\
$50^{\circ}$ & $21.1 \mathrm{a}$ & $1 / 2$ & $23.8 \mathrm{a}$ \\
$70^{\circ}$ & $24.3 \mathrm{a}$ & & \\
$90^{\circ}$ & $28.7 \mathrm{a}$ & & \\
$\mathrm{LSD}$ & 7.68 & LSD & 5.43 \\
$P$ & 0.01 & $P$ & 0.03 \\
\hline${ }^{ } 1$ inch $=25.4$ mm. & & & \\
'Values within a column followed by the same letter are not significantly different at \\
$P \leq 0.05$ by protected Fisher's protected least significant difference (LSD).
\end{tabular}


common bermudagrass sports field with a native clay soil. Bunnell et al. (2001) noted a $40 \%$ infiltration rate increase using hollow tine $(2 / 3$-inch diameter and 3.5-inch tine depth) cultivation treatment compared to untreated on a sand-based 'Crenshaw' creeping bentgrass putting green. $\mathrm{Al}-$ though not measured, the decrease in water infiltration for untreated plots is probably indicative of excessive thatch accumulation over the 2-year period of this study. Excessive thatch accumulation occurs when soil organic matter production rate exceeds decomposition rate (Beard, 1973). This process is often accelerated in creeping bentgrass cultivars due to their aggressive horizontal growth habits and limited vertical growth (McCarty et al., 2005), which may quickly develop into thatch in absence of cultivation.

In conclusion, based on results, different core cultivation tine entry angles had no significant impacts on parameters measured. However, 1/4inch hollow tines enhanced TQ in year I, but increased MED scores 6\%. Also, soil hydrophobicity decreased from June to October. Following 2 years of core cultivation, water infiltration was improved compared to the untreated. Future studies should focus on duration and alternative tines. Increasing the study duration to 4 or 6 years may have a greater impact on water infiltration and MED results as soil properties may require a greater duration to alter. Also, future studies using deeper tines with different diameters of similar tine entry angles into the soil profile is needed.

\section{Literature cited}

Beard, J.B. 1973. Turfgrass: Science and culture. Prentice Hall, Englewood Cliffs, N.J.

Brown, P.J. 2004. The relief of soil compaction on heavily trafficked sports fields. MS Thesis, Clemson Univ., Clemson, S.C.

Bunnell, B.T., L.B. McCarty, and H.S. Hill. 2001. Summer cultivation effects on a sand based creeping bentgrass golf green. Intl. Turfgrass Soc. Res. J. 9:3-9.

Carrow, R.N. and A.M. Petrovic. 1992. Effects of traffic on turfgrasses. p. 285-330. In: D.V. Waddington, R.N. Carrow, and R.C. Shearman (eds.). Turfgrass. Agron. Monogr. No. 32. Amer. Soc. Agron., Madison, Wis.

Fry, J. and B. Huang. 2004. Applied turfgrass science and physiology. Wiley, Hoboken, N.J.

Guertal, B. and D. Han. 2002. Does aerification help solve compaction problems? Turfgrass Trends 11(2):T4, T6-T7, T10.

Guertal, E.A., C.L. Derrick, and J.N. Shaw. 2003. Deep-tine aerification in compacted soil. Golf Course Mgt. 71(12):87-90.

Hartwiger, C. and P. O'Brien. 2001. Core aeration by the numbers. USGA Green Section Record 39(4):8-9.

Hollingsworth, B.S., E.A. Guertal, and R.H. Walker. 2005. Cultural management and nitrogen sources effects on ultradwarf bermudagrass cultivars. Crop Sci. 45:486-493.

Jones, M. 2002. Linear aerification encourages good soil respiration. Turfgrass Trends $11(4): \mathrm{T} 15-\mathrm{T} 16$.

King, P.M. 1981. Comparison methods for measuring severity of water repellency of sandy soils and assessment of some factors that affect measurement. Austral. J. Soil Res. 19:275-285.

McCarty, L.B. 2005. Best golf course management practices, 2 nd ed. Prentice-Hall, Upper Saddle River, N.J.

McCarty, L.B., M.F. Gregg, J.E. Toler, J.J. Camberato, and H.S. Hill. 2005. Minimizing thatch and mat development in a newly seeded creeping bentgrass golf green. Crop Sci. 45:1529-1535.

Miller, R.H. and J.F. Wilkinson. 1979. Nature of the organic coating on sand grains of nonwettable golf greens. Soil Sci. Soc. Amer. J. 41:1203-1204.

Murphy, J.A. and P.E. Rieke. 1994. High pressure water injection and core cultivation of a compacted putting green. Agron. J. 86:719-724.

Murphy, J.A., P.E. Reike, and A.E. Erickson. 1993. Core cultivation of a putting green with hollow and solid tines. Agron. J. 85:1-9.

Tucker, K.A., K.J. Karnok, D.E. Radcliffe, G. Landry Jr., R.W. Roncadori, and K.H. Tan. 1990. Localized dry spots caused by hydrophobic sands on bentgrass greens. Agron. J. 82:549-555.

U.S. Golf Association Green Section Staff. 1993. USGA recommendations for a method of putting green construction. The 1993 revision. USGA Green Section Record 31(2):1-3

White, R.H. and R. Dickens. 1984. Thatch accumulation in bermudagrass as influenced by cultural practices. Agron J. 68:257-260.

Wilkinson, J.F. and R.H. Miller. 1978. Investigation and treatment of localized dry spots on sand golf greens. Agron J. 70:299-304. 